\title{
KEMANDIRIAN BELAJAR MENUJU PEMBELAJAR YANG BAHAGIA
}

\author{
Asina Christina Rosito \\ Fakultas Psikologi, Universitas HKBP Nommensen
}

\begin{abstract}
Abstrak
Merebaknya COVID 19 di seluruh dunia pada umumnya, dan di Indonesia pada khususnya, merubah tatanan kehidupan masyarakat yang selama ini berlangsung. Perubahan yang paling siginifikan dalam aspek kesehatan, pendidikan, industri dan ekonomi, serta pola hubungan sosial masyarakat. Penggunaan teknologi dan internet menjadi kebutuhan utama bagi masyarakat dalam menjalani masa pandemi COVID 19 ini. Dengan kebijakan dari pemerintah untuk belajar dari rumah, wajah pendidikan di Indonesia mengalami perubahan signifikan. Belajar tidak lagi dibatasi oleh ruang dan kelas, karena belajar bisa dimana saja, kapan saja, dan sumber belajar yang tidak terbatas. Namun, disisi lain, keleluasaan dalam belajar ini belum dibarengi dengan kesiapan dari para pihak yang terlibat dalam pendidikan itu sendiri, terutama para pelajar dan mahasiswa. Banyak keluhan psikologis yang semakin intens muncul dari para pelajar dan mahasiswa, terkait model pembelajaran ini. Dibutuhkan program-program psikologi dalam melatih softskills para pelajar dan mahasiswa dalam mengelola belajarnya sehingga dapat mengelola stress yang dihadapi, dan bahagia dalam menjalani pross pembelajaran daring.
\end{abstract}

Kata Kunci: Pembelajaran Jarak Jauh, COVID 19, Pembelajar Mandiri

\begin{abstract}
The spread of COVID 19 throughout the world, especially in Indonesia has changed the way how people live. Some significant changes including medical, education, economy, and social relations. The use of technology and the internet are necessity for people in adapting to the corona viruses' impact. Indonesia's government has issued policy to learn from home, so that the face of education in this country has changed significantly. Learning is no longer done in schools building because learning can be done anywhere, anytime, with unlimited learning resources in internet. However, this flexibility in learning has not been supported by the learner readiness in many level of education, including in higher education. There are complaints from student related to the distance learning system. Psychology programs are needed in order to improve students' soft skills in managing their learning to be a self-regulated learner, so that they can manage the obstacles they face, and be happy in undergoing the distance learning process.
\end{abstract}

Keywords: Distance Learning, COVID 19, Self-Regulated Learning

Correspondence author: Asina Christina Rosito, asina.christina@hotmail.com, Medan, Indonesia

\section{PENDAHULUAN}

Pada bulan Maret 2020, pemerintah menyatakan bahwa Indonesia memasuki masa gawat darurat dikarenakan kehadiran COVID 19 (Corona Virus Desease 19). Merebahnya virus ini memberi perubahan dalam berbagai aspek kehidupan manusia. Salah satu bidang kehidupan yang terkena dampak adalah bidang kesehatan, dimana dunia kesehatan dikejutkan dengan virus yang berpotensi membawa kematian ini. Berbagai kajian dan riset dilakukan tentang virus ini, sebagai upaya untuk dapat 
menjelaskan bagaimana virus ini bekerja, sampai dengan berbagai penanganan untuk berusaha memulihkan kondisi kesehatan individu yang terinfeksi virus ini. Berbagai perusahaan farmasi dan laboratorium kesehatan baik yang sifatnya swasta, maupun yang berada di bawah naungan institusi pendidikan, dari berbagai negara di belahan dunia, berusaha menemukan vaksin untuk mengatasi virus ini. Uji coba vaksin yang ditemukan, sudah dalam tahap uji coba di beberapa negara, termasuk di Indonesia. Namun demikian, hingga bulan September 2020 ini, kecenderungan dari jumlah individu yang terinfeksi virus ini masih meningkat, dimana pada tanggal 28 September 2020, yang positif terinfeksi COVID 19 mencapai 3.509 kasus (sumber:covid 19.go.id)

Perubahan signifikan lainnya sebagai dampak dari kebijakan pemerintah yang memberlakukan social distancing dan physical distancing, sebagai upaya utama mencegah penyebaran virus ini, adalah dalam bidang pendidikan. Sesuai instruksi dari Menteri Pendidikan dan Kebudayaan, Nadiem Makarim, pembelajaran tatap muka di kelas dihentikan, dan beralih menjadi pembelajaran daring (jarak jauh). Hal ini diberlakukan untuk semua jenjang pendidikan, dari pendidikan anak usia dini hingga pendidikan tinggi. Kebijakan untuk 'belajar dari rumah' ini membawa beberapa dampak positif dan dampak negatif. Dampak positifnya antara lain adalah terhindarnya penyebaran COVID 19 di antara para pelajar, mahasiswa dan para tenaga kependidikan. Selain itu, para pengajar dan pelajar, menjadi lebih kreatif dalam pembelajaran dan dalam berbagai upaya pengembangan diri lainnya. Para dosen dan guru mulai belajar membuat youtoube channel sebagai media untuk menyampaikan berbagai materi pembelajaran. Para pelajar dan mahasiswa juga mulai mempelajari hal-hal baru, antara lain menggunakan berbagai aplikasi atau program untuk membuat presentasi menarik, flyer, dan lain sebagainya. Dari hasil wawancara singkat penulis dengan mahasiswa, ada banyak keterampilan baru yang mereka peroleh selama masa pandemi ini antara lain membuat video presentasi menarik, belajar tentang bisnis online, belajar terkait memasak, membuat blog pribadi, dan lainnya.

Disisi lain, banyak masalah dan kesulitan yang dialami oleh mahasiswa di dalam masa pembelajaran daring ini. Dari hasil diskusi penulis dengan mahasiswa, setidaknya ada dua masalah besar yang mereka alami selama pembelajaran daring di masa pandemi ini. Pertama, kendala teknis yang terjadi seperti jaringan internet yang tidak stabil, keterbatasan jaringan internet di daerah dia berada, kekurangan dana 
untuk membeli kuota, dan kekurangan sarana seperti laptop atau komputer. Hal ini semakin rumit terjadi ketika mahasiswa berada di tempat asalnya, yang relatif berada di daerah yang sulit dijangkau. Kedua, terkait dengan pembelajaran daring, mahasiswa mengeluhkan banyaknya tugas rumah yang perlu dilakukan secara mandiri. Sementara itu penguasaan terhadap materi masih kurang, dan ada keterbatasan interaksi antara dosen-mahasiswa, dan antar mahasiswa. Ketika mereka tidak mampu menemukan solusi atas kesulitan-kesulitan ini, maka hal ini dapat menyebabkan mahasiswa stres dan akhirnya berdampak pada kesehatan psikologis dan fisik mereka.

Survey yang dilakukan oleh Kusnayat, Muiz, Sumarni, Mansyur dan Zaqiah (2020) terhadap mahasiswa Telkom University dan UIN SGD Bandung, menunjukkan bahwa sebagian besar dari reseponden mahasiswa (47\% untuk mahasiswa Telkom Universiy dan 72 \% untuk mahasiswa UIN SGD Bandung) mempersepsikan bahwa dosen memberikan tugas yang berlebihan dibandingkan dengan pembelajaran di kelas, selama perkuliahan daring dilakukan. Tugas yang berlebihan ini menjadi salah satu sumber stress bagi mereka. Hal ini dikonfirmasi lebih lanjut dimana, pada responden mahasiswa Telkom University, 70 \% mengaku sulit tidur ketika memikirkan tugastugas tersebut. Pada responden mahasiswa dari UIN SGD Bandung, 50 \% mengaku mengalami kesulitan tidur ketika memikirkan tugas-tugas tersebut. Lebih lanjut, sebanyak 34\% mahasiswa Telkom University merasa kesulitan menggunakan aplikasi pembelajaran online, dan $31 \%$ mahasiswa UIN SGD Bandung mengalami kesulitan yang sama. Ketika dihadapkan dengan pernyataan "Saya lebih suka perkuliahan tatap muka”, sebanyak 90 \% responden mahasiswa Telkom University dan 94 \% responden mahasiswa UIN SGD Bandung setuju dengan pernyataan tersebut.

Survey lain yang dilakukan oleh Harahap, Harahap, dan Harahap (2020) terhadap 300 orang mahasiswa UINSU Medan dalam masa perkuliahan daring, menunjukkan bahwa sebanyak 39 mahasiswa (13\%) yang memiliki tingkat stres akademik kategori tinggi, sebanyak 225 mahasiswa (75\%) memiliki tingkat stres akademik pada kategori sedang, dan sebanyak 36 mahasiswa (12\%) memiliki tingkat stres akademik yang berada pada kategori rendah. Dapat disimpulkan, bahwa sebagian besar responden mahasiswa mengalami stress dalam mengikuti perkuliahan daring.

Studi kualitatif yang dilakukan oleh Nisa dan Putri (2020) terhadap mahasiswa 255 mahasiswa program studi kesehatan masyarakat Universitas 
Airlangga, menemukan bahwa setidaknya ada 3 dampak dari diberlakukannya kebijakan belajar dari rumah, yang terindetifikasi, yakni pertama, kesulitan dalam atasi masalah-masalah yang terkait dengan belajar daring, misalnya jaringan internet dan tugas yang banyak. Mahasiswa perlu mencari cara dan solusi untuk atasi masalah keterbatasan jaringan internet, dan mengelola waktu dan sumber daya untuk atasi masalah tugas yang banyak. Kedua, biaya yang dikeluarkan untuk menunjang pembelajaran daring bertambah, dari yang biasanya, dikarenakan harus menyediakan kuota internet yang memadai, dimana salah satu caranya adalah dengan memasang jaringan wifi di rumah. Ketiga, social isolation, dimana para mahasiswa yang berada pada tahap perkembangan remaja akhir sedang dalam tahapan dimana adanya kebutuhan yang kuat untuk berinteraksi sosial sedang teman-temannya, namun dibatasi dikarenakan kebijakan untuk "stay at home".

Dinamika pembelajaran di perguruan tinggi tentunya mempunyai perbedaan tersendiri dimana pada tahap ini, biasanya pendampingan orangtua tidak terlalu intens, dikarenakan mahasiswa dianggap sudah mampu untuk mandiri. Namun, tidak dapat dipungkiri bahwa mahasiswa pun mengalami kesulitan dalam mengelola waktu dan mengelola belajarnya. Pada dasarnya, kemampuan untuk mengelola pembelajaran adalah keterampilan yang signifikan bagi seorang pembelajar, pada tiap jenjang pendidikan dan tahapan usia. Kemampuan untuk mengelola pembelajaran ini disebut dengan self-regulated learning, dimana konsep ini berakar dari konsep self-regulation. Bagaimana pembelajar mengelola dan mengatur pembelajarannya merupakan faktor signifikan penentu pencapaian akademiknya. Berbagai penelitian terdahulu mencoba mengeksplorasi faktor-faktor apa saja yang mempengaruhi pencapaian akademik dari seorang pembelajar. Beragam hasil pun diperoleh dengan kesimpulan umum bahwa kemampuan kognitif (misal: inteligensi) tidak menjamin pencapaian akadamik atau prestasi belajar. Pencapaian pembelajar tidak dapat secara menyeluruh dijelaskan oleh keterampilan dan kapasitas individu, melainkan ada juga peran faktor regulasi diri dan motivasi (Zimmerman, 2001 dalam Schunk, 2005). Regulasi dalam konteks pembelajaran disebut sebagai self-regulatory learning dilihat sebagai mekanisme yang dapat menjelaskan adanya perbedaan dalam pencapaian belajar di antara para pembelajar dan juga dapat dilihat sebagai alat untuk meningkatkan pencapaian belajar. Oleh karena itu, seorang pembelajar perlu mengembangkan self-regulated 
learning.Menurut Pintrich (2000, dalam Schunk, 2005) self-regulated learning adalah suatu proses konstruktif dan aktif dimana pembelajar menetapkan tujuan belajarnya dan berusaha untuk memonitor, mengelola dan mengontrol kognisi, motivasi, dan perilakunya, dengan mengacu pada tujuan yang ditetapkan dan kondisi lingkungan. Santrock (2004) menyatakan bahwa self-regulated learning merupakan kemampuan untuk memonitor sendiri baik itu pikiran, perasaan, dan perilaku demi mencapai suatu tujuan. Tujuan yang dimaksud disini, bisa berkaitan dengan akademik misalnya meningkatkan pemahaman tentang membaca, menulis, menghitung, dan lain sebagainya. Selain itu, bisa juga tujuannya berhubungan dengan tujuan sosioemosional seperti mengontrol kemarahan, belajar membangun relasi dengan teman, dan sebagainya.

Menurut Zimmerman (2002), pembelajar dengan self-regulated learning yang tinggi adalah mereka yang aktif mengarahkan energi, kognitif, dan perilakunya dalam proses belajar. Mereka bertahan ketika menghadapi kesulitan atau tantangan dalam belajarnya. Mereka juga mencoba berbagai strategi belajar yang berbeda untuk mengoptimalkan hasil belajarnya.

Situasi belajar daring, menuntut adanya kemampuan mahasiswa dalam mengarahkan, mengelola, memantau, dan mengevaluasi belajarnya secara mandiri. Hal ini menjadi satu tugas penting bagi mahasiswa. Mengingat bahwa kapasitas ini dapat dilatih dan dikembangkan, maka adalah penting untuk membantu para mahasiswa untuk meningkatkan kemampuan regulasi belajarnya, menuju pembelajar yang mandiri.

Beberapa manfaat dari self-regulated learning ini antara lain adalah meningkatnya konsentrasi dan motivasi dalam melakukan berbagai aktivitas pembelajaran, memilik disiplin diri, meningkatkan prestasi akademik, meningkatkan efisiensi dalam mempelajari pengetahuan dan keterampilan baru, menurunkan perilaku prokrastinasi, lebih adaptif terhadap perubahan, lebih terbuka dalam menerima kritikan atau masukan, dan meningkatkan keyakinan terhadap kemampuan diri (Mangunsong, 2020).

Berdasarkan latar belakang masalah, hasil penelusuran literatur dan pengalaman pribadi penulis sebagai dosen, seperti yang dipaparkan di atas, maka dipandang perlu untuk melakukan kegiatan atau program yang dapat membekali 
mereka untuk mampu menjalani masa pembelajaran daring ini dengan baik. Maka dari itu, dilakukanlah seminar secara online kepada para mahasiswa dan pelajar, yang terkait dengan bagaimana mengembangkan kemampuan regulasi belajar dan menyenangkan di masa pembelajaran daring ini. Adapun tujuan utama dari kegiatan ini adalah membekali mahasiswa dan pelajar tentang mengembangkan kemampuan regulasi belajar (self-reguleted learning).

\section{METODE PELAKSANAAN}

Tahapan dalam perencanaan kegiatan pengabdian masyarakat ini dapat dibagi dalam 2 bagian besar:

1. Tahap perumusan masalah

Berdasarkan analisis terhadap masalah yang dialami oleh mahasiswa dan pelajar dalam menjalani pembelajaran daring, maka diusulkan agar dilakukan program pengabdian masyarakat berupa seminar online, dengan tema pembelajaran mandiri menuju pembelajar yang bahagia, dengan judul "Happy online learning".

2. Tahap menentukan waktu dan mekanisme pelaksanaan Pada tahap ini, ditentukan tanggal pelaksanaan yang tepat, mengingat semester baru, yaitu semester ganjil TA. 2020/2021, akan dimulai. Maka, dipandang baik untuk melakukan kegiatan ini menjelang semester baru dimulai. Mengingat bahwa kampus belum diperkenankan oleh pemerintah untuk melakukan perkuliahan tatap muka, dimana para mahasiswa sebagian besar berada di daerah asal masing-masing, maka pelaksanaan kegiatan dilaksanakan secara daring, melalui aplikasi zoom.

3. Tahap publikasi kegiatan

Publikasi kegiatan dilakukan seminggu sebelum kegiatan berlangsung, dengan menggunakan berbagai media sosial, seperti WA, instagram, dan facebook. Publikasi berbasis media sosial ini, dipandang efektif dari segi biaya, waktu, dan luas jangkauan penyebaran informasinya. Pada tahap ini, dipersiapkan juga tautan pendaftaran online menggunakan google form, yang disebarkan bersamaan dengan flyer publikasi kegiatan. 
Persiapan

Persiapan disini mencakup mempersiapkan pihak yang terlibat dalam pelaksanan seminar antara lain menentukan host, MC dan moderator; persiapan materi oleh narasumber, terkait dengan tema dan tujuan yang disusun.

4. Pelaksanaan

Adapun rincian dari kegiatan seminar online ini adalah sebagai berikut:

Tanggal pelaksanaan

Pukul

Peserta

Judul seminar

Tempat

Narasumber
: Sabtu, 12 September 2020

: 14.00 WIB sampai dengan 16.00 WIB

: mahasiswa, pelajar, guru dan dosen

: Happy online learning

: zoom meeting room

: Asina Christina Rosito, S.Psi, M.Sc.

\section{HASIL DAN PEMBAHASAN}

Pelaksanaan kegiatan pengabdian masyarakat dalam bentuk seminar online dilakukan pada hari Sabtu, 12 September 2020, dari pukul 14.00 WIB sampai dengan 16.00 WIB.

Kegiatan seminar ini dengan diawali oleh aktivitas games bersama, dimana setiap peserta diajak untuk bermain "mencari benda", dimana dalam aktivitas ini, peserta diminta untuk mencari benda disekitarnya dengan warna-warna tertentu, seperti warna putih, hitam, dan ungu. Tujuan dari kegiatan ini adalah sebagai ice breaking, untuk membangun suasana senang dan ceria bagi semua peserta seminar.

Sesi berikutnya adalah sesi pemaparan oleh narasumber, dalam hal ini adalah penulis sendiri, sebagai pengajar, pemerhati pendidikan, dan juga peneliti yang banyak menyoroti tentang pembelajarn di tingkat perguruan tinggi. Pada sesi ini, narasumber memaparkan tentang realita COVID 19 dan dampaknya terhadap proses pendidikan secara umum, dan secara khusus dalam pembelajaran daring. Tujuan dari bagian ini adalah mengajak peserta untuk menyadari dan menerima realita kondisi bangsa ini, dan kaitannya dengan peserta baik sebagai mahasiswa, pelajar, guru, dosen, dan orangtua, dalam kaitannya dengan pembelajaran online. Dari point of view ini, narasumber mengajak para peserta untuk menerima bahwa pembelajaran daring 
adalah bagian yang tidak dapat dihindari di masa kini. Jadi, diharapkan para peserta terbangun kesadarannya akan pembelajaran daring sebagai kenyataan yang dapat dilihat dari sudut pandang yang positif, tidak melulu dari sudut pandang yang negatif. Meskipun respon dari beberapa peserta masih ada yang mengatakan bosan dengan situasi belajar daring, namun narasumber mengajak untuk menemukan hal positif dan mengembangkan keterampilan-keterampilan baru selama belajar daring di rumah.

Selanjutnya, narasumber mengajak peserta untuk mengenali satu strategi mendasar untuk dapat menghindari stress dan menjalani pembelajaran daring dengan efiktif dan optimal, yaitu keterampilan mengelola pembelajaran, menuju seorang pembelajar yang mandiri. Dalam memaparkan indikator-indikator dari pembelajar mandiri ini, narasumber mengacu pada teori self regulated learning yang dikemukakan oleh Pintrich (2000, dalam Schunk, 2005), yang mencakup efikasi diri, menetapkan tujuan (goal setting), melakukan perencanaan (planning), melakukan upaya memotivasi diri, mengeksplorasi berbagai strategi belajar, melakukan pemantauan (monitoring) terhadap proses belajar, menciptakan suasana lingkungan belajar yang kondusif, mencari bantuan ketika diperlukan dan melakukan evaluasi (evaluation) terhadap belajar.

Pada sesi terakhir, para peserta diberi kesempatan untuk menyampaikan pertanyaan baik itu klarifikasi, penjelasan, atau hal lainnya yang relevan dengan pemaparan yang diberikan. Dari sesi ini, narasumber juga dapat memperoleh gambaran pemahaman dari para peserta akan materi yang diberikan.

Hasil dari kegiatan pengabdian masyarakat ini dapat dilihat dari 4 (empat) komponen antara lain:

1. Ketercapaian tujuan seminar online "happy online learning" dan target materi Tujuan dari seminar pengabdian masyarakat ini adalah agar mahasiswa dan pelajar dibekali dengan pemahaman, pengetahuan dan keterampilan untuk mengelola pembelajarannya dengan efektif, sehingga mampu menjadi pembelajar yang mandiri, optimis, dan bahagia.

2. Ketercapaian jumlah peserta seminar online

Pendaftaran kegiatan ini dilakukan secara online, melalui link goggle form pendaftaran yang dapat dishare melalui wa atau media sosial lainnya. publikasi dan pendaftaran dimulai pada satu minggu sebelum pelaksanaan 
seminar online. Sampai dengan hari $\mathrm{H}-1$, pendaftar untuk kegiatan ini berjumlah 90 orang, yang mayoritas adalah mahasiswa dan pelajar. Dari jumlah peserta yang mendaftar tersebut, sekitar 50 orang mengikuti seminar online ini. Beberapa kemungkinan penjelasan dari ketidakhadiran peserta yang telah mendaftar antara lain, kendala teknis seperti jaringan, atau adanya kegiatan lain yang bersamaan waktunya, dan lain sebagainya.

3. Antusiasme peserta dalam bertanya

Secara umum pertanyaan yang muncul terkait dengan bagaimana strategi untuk meningkatkan minat belajar untuk mata pelajaran atau mata kuliah yang kurang menarik, strategi untuk tetap semangat dan senang dalam pembelajaran daring, dan ada juga pertanyaan terkait strategi yang dapat dilakukan orangtua agar anak yang sedang belajar daring tidak menyalahgunakan sarana yang ada seperti untuk games, dan lain sebagainya yang tidak relevan dengan pembelajaran

4. Ketercapaian kemampuan peserta dalam memahami materi Setelah seminar online dilakukan, diberikan tautan google form feedback kepada para peserta, sebagai salah satu bentuk evaluasi terhadap pelaksanaan seminar ini. Dari hasil evaluasi tersebut, beberapa hal dapat disimpulkan terkait dengan persepsi peserta akan proses seminar online yang telah berlangsung. Pertama, muatan materi dalam seminar ini relevan dengan kebutuhan para mahasiswa dan pelajar yang mengikuti perkuliahan secara daring Kedua, seminar ini memberikan insight dan membangkitkan semangat bagi para peserta. Ketiga, ada saran agar durasi waktu seminar tidak terlalu lama. Keempat, ada saran untuk melakukan kegiatan seminar pengembangan diri seperti ini secara berkelanjutan.

Berikut ini adalah beberapa dokumentasi dari kegiatan seminar online ini. 


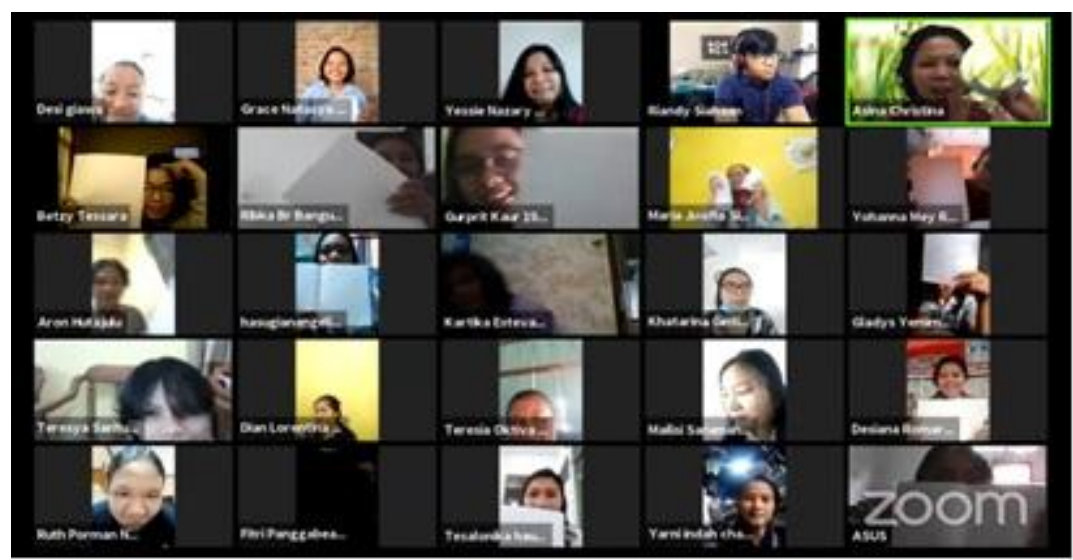

Gambar 1. Aktivitas Games Bersama

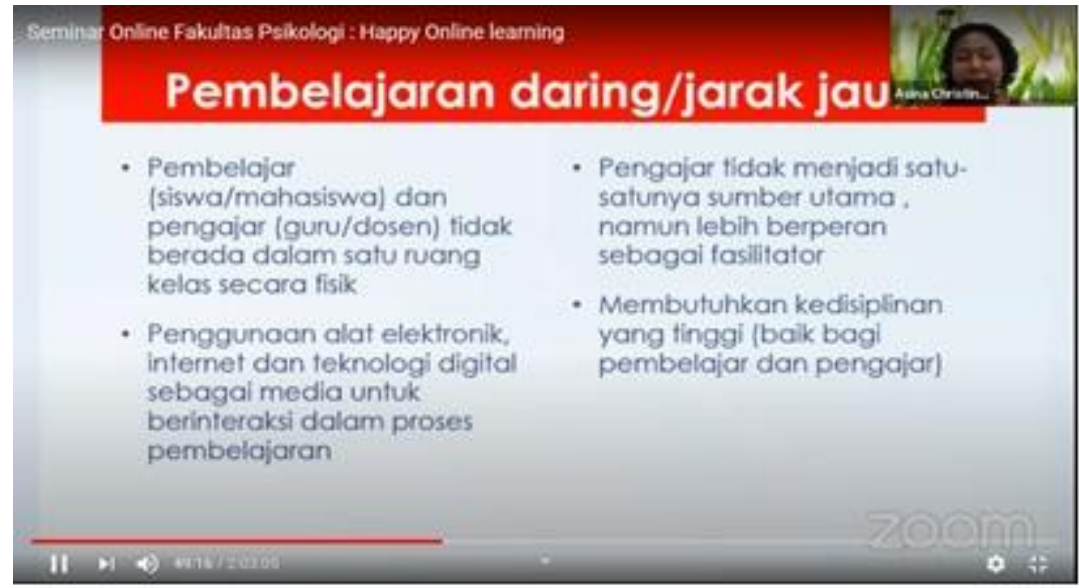

Gambar 2. Penyampaian Materi

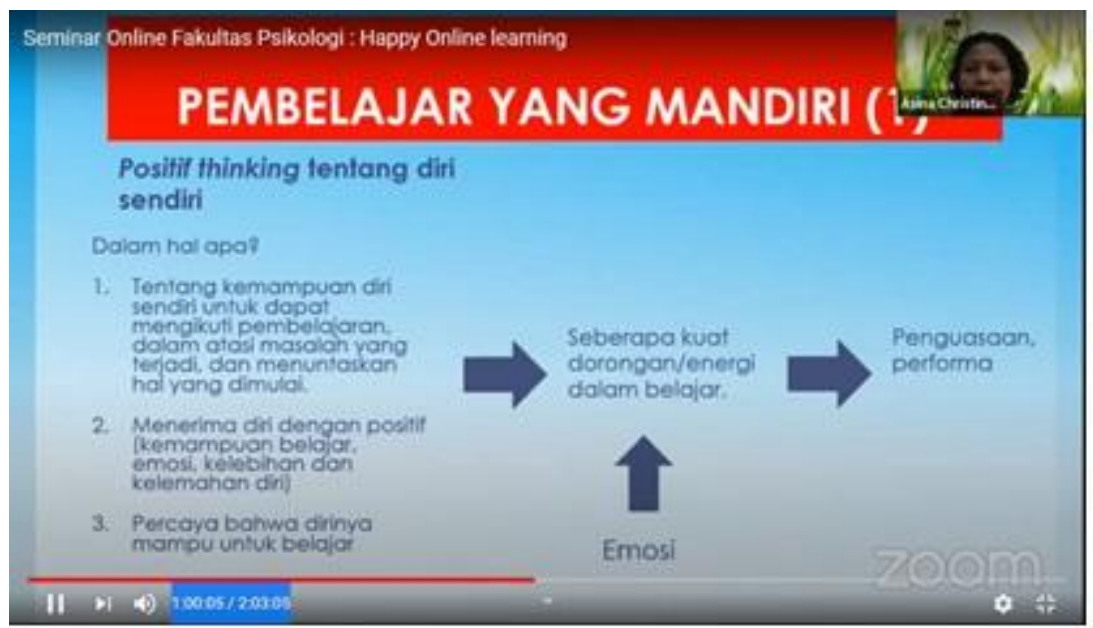

Gambar 3. Penyampaian Materi 


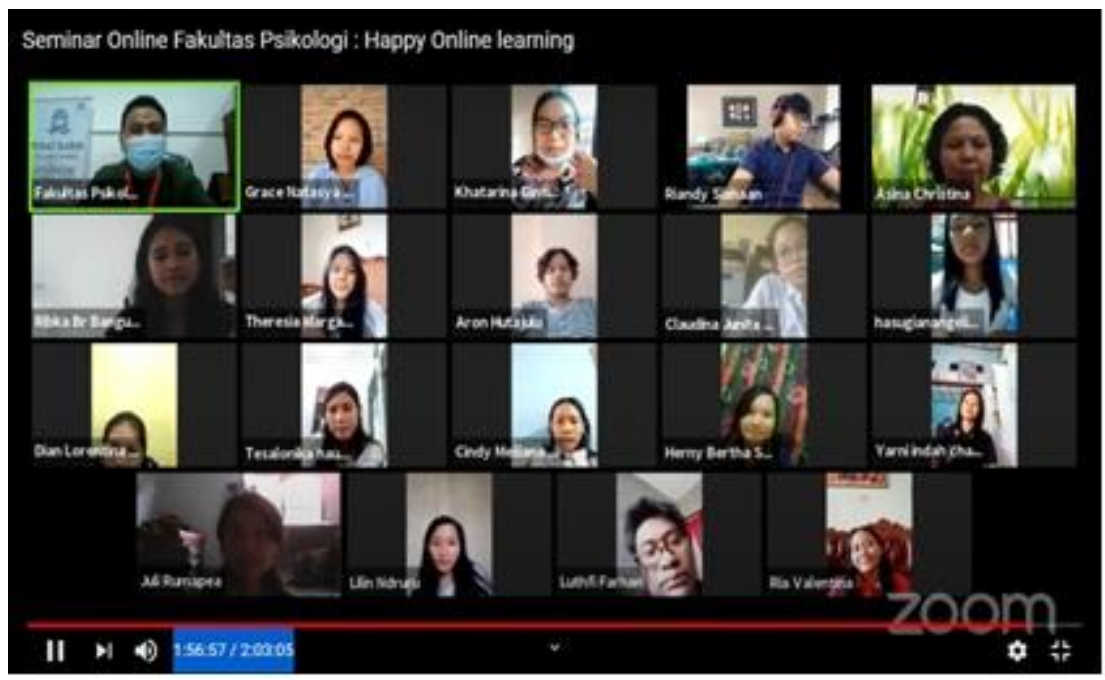

Gambar 4. Sesi Penutupan Seminar

\section{KESSIMPULAN}

Kegiatan pengabdian masyarakat ini dilakukan dengan tujuan untuk membekali mahasiswa dan pelajar tentang pengetahuan dan keterampilan untuk mengelola pembelajaran secara mandiri, menuju pembelajar yang optimal dan bahagia. Beberapa saran praktis yang dapat diberikan berdasarkan hasil kegiatan pengabdian masyarakat ini adalah, pertama, masih dibutuhkannya kegiatan serupa, yang diperuntukkan bagi para mahasiswa dan pelajar. Mengingat keterampilan belajar secara mandiri dan bahagia adalah suatu kapasitas yang diperoleh melalui pengalaman dan latihan mandiri, artinya keterampilan belajar mandiri ini dapat dilatih dan dikembangkan. Maka dari itu, mengingat dibutuhkannya keterampilan ini secara terus menerus dan berkesinambungan, adalah perlu melakukan kegiatan serupa, bisa seminar atau pelatihan/workshop sebagai tindak lanjut dari kegiatan seminar ini. Kedua, beberapa tema besar lain yang terkait dengan belajar mandiri ini masih perlu dieksplorasi lagi untuk dikembangkan menjadi program seminar atau pelatihan/workshop seperti manajemen waktu, communication skill, literacy skill,dan lain sebagainya.

\section{DAFTAR PUSTAKA}


Harahap, A.C.P., Harahap, D.P, Harahap, S. R. (2020).,Analisis Tingkat Stres Akademik Pada Mahasiswa Selama Pembelajaran Jarak Jauh Dimasa Covid-19, Jurnal Kajian Konseling dan Pendidikan 3, (1), 10-14

Kusnayat, A., Muiz, M. H., Sumarni, N., Salim, A., Mansyur, \& Zaqiah, Q. Y. (2020).,Pengaruh teknologi pembelajaran kuliah online di era covid-19 dan dampaknya terhadap mental mahasiswa,EduTeach :Jurnal Edukasi dan Teknologi Pembelajaran, 1, (2), 153-163

Mangunsong, F. S. (2020).,Merdeka Belajar, Dapat diakses di (https://www.youtube.com/watch?v=-ar5FHwQTUc).

Nisa, D.F. \& Putri, N.K (2020).,Bagaimana Wabah Virus Corona Mempengaruhi Kehidupan Mahasiswa?, Laporan Penelitian. Universitas Arilangga

Santrock, J. W. (2004).,Psikologi Pendidikan, Edisi Kedua, Kencana, Prenada Media Group, Jakarta.

Schunk,D. H. 2005. Self-Regulated Learning: The Educational Legacy Of Paul R. Pintrich, Educational Psychologist, 40, 85-94

Zimmerman, B. J. 2002.,Becoming a self-regulated learner: An overview, Theory into Practice, 41, 64-70 